\title{
Helicobacter pylori serum IGG'si pozitif olan larengofarengeal reflülü olgularda total antioksidan kapasite, total oksidan seviye ve oksidatif stres indeksi
}

\author{
Total antioxidant capacity, total oxidant level and oxidative stress index in patients with \\ laryngopharyngeal reflux with Helicobacter pylori IGG positivity
}

\author{
Önder Mutlu', Murat Kar², Fadile Yıldız Zeyrek³ ${ }^{3}$ Nurten Aksoy ${ }^{4}$, Abdullah Taşkın \\ ${ }^{1}$ Tatvan Devlet Hastanesi, Kulak Burun Boğaz Hastalıkları Kliniği, Bitlis \\ ${ }^{2}$ Kumluca Devlet Hastanesi, Kulak Burun Boğaz Hastalıklar Kliniği, Antalya \\ ${ }^{3}$ Harran Üniversitesi Tıp Fakültesi, Mikrobiyoloji Anabilim Dalı, Şanhurfa \\ ${ }^{4}$ Harran Üniversitesi T⿰р Fakiiltesi, Biyokimya Anabilim Dal, Şanluurfa
}

\begin{abstract}
Özet
Amaç: Bu çalışmanın amacı, larengofarengeal reflü (LFR) hastalarında, H. pylori serum IgG pozitifliği, total antioksidan kapasite, total oksidan seviye ve oksidatif stres indeksi arasındaki ilişkiyi araştırmaktır.

Yöntem: Larengofarengeal reflü (LFR) şikayeti ile başvuran 48 hasta çalışma grubuna alınmıştır. Bu hastalardan, H. pylori IgG (-), LFR (+) olan 20 hasta Grup 2 ve H. pylori IgG (+), LFR (+) olan 28 hasta Grup 3 olarak çalışmaya alınmıştır. Kontrol grubunu (Grup 1) ise, 19 sağlıklı birey oluşturmuştur. Tüm gruplarda, total antioksidan kapasite, total oksidan seviye ve oksidatif stres indeksi çalışılmıştır.

Bulgular: Grup 3'ün total oksidan seviye değerleri, Grup 1 ( $\mathrm{p}=0.000)$ ve Grup 2'den ( $\mathrm{p}=0.000$ ) ve Grup 2'nin total oksidan seviye değerleri ise, Grup 1'den istatistiksel olarak anlamlı şekilde daha yüksekti. Grup 3'ün oksidatif stres indeksi değerleri, Grup $1(\mathrm{p}=0.000)$ ve Grup 2'den ( $\mathrm{p}=0.000)$, Grup 2'nin oksidatif stres indeksi değerleri, Grup 1 'den ( $\mathrm{p}=0.001)$ istatistiksel olarak anlamlı şekilde daha yüksekti.

Sonuç: Tek başına LFR varlığı veya LFR ve $H$. pylori'ye karşı gelişen serum IgG antikor seviyesindeki artış, total oksidan seviye ve oksidatif stres indeksinde artmaya yol açmaktadır. Hem LFR hem de $H$. pylori ile enfekte olunması ve $H$. pylori'ye karşı IgG antikorlarının gelişmesi, vücutta total oksidan seviye ve oksidatif stres indeksinde artışa yol açarak, sonuçta serbest radikallerde artışa ve vücutta oksidatif streste artışa yol açmaktadır.
\end{abstract}

Anahtar sözcükler: Helicobacter pylori, total antioksidan kapasite, total oksidan seviye, oksidatif stres indeksi.

\begin{abstract}
Objective: The aim of this study is to investigated the relationship between $H$. pylori IgG positivity, total antioxidant capacity (TAC), total oxidant level (TOL) and oxidative stress index (OSI) in patients with laryngopharyngeal reflux (LPR).

Methods: A total of 48 patients with laryngopharyngeal reflux (LPR) were included into the study group. Of these patients, 20 with $H$. pylori $\operatorname{IgG}(-)$, LPR (+) were included into Group 2; and 28 patients with $H$. pylori $\operatorname{IgG}(+)$, LPR (+) were included into Group 3. The control group (Group 1) consisted of 19 healthy subjects. In all groups, total antioxidant capacity, total oxidant level and oxidative stress index were studied. Results: Group 3's total oxidant level values were significantly higher than those of Group 1 ( $\mathrm{p}=0.000)$ and Group 2 ( $\mathrm{p}=0.000)$; and Group 2's total oxidant level values were significantly higher than Group 1. Group 3's oxidative stress index values were significantly higher than those of Group $1(\mathrm{p}=0.000)$ and Group $2(\mathrm{p}=0.000)$, and Group 2's oxidative stress index values were significantly higher than Group $1(\mathrm{p}=0.001)$.

Conclusion: The presence of LFR alone, or LFR and increase in the level of serum IgG antibody developed against $H$. pylori, lead to increase in total oxidant level and oxidative stress index. Both LPR and to be infected with $H$. pylori and development of $H$. pylori IgG antibodies lead to an increase in total oxidant level and oxidative stress index; and an increase in free radicals ultimately lead to an increase in oxidative stress in the body.
\end{abstract}

Key words: Helicobacter pylori, total antioxidant capacity, total oxidant level, oxidative stress index.

\footnotetext{
İletişim / Correspondence: Dr. Murat Kar. Kulak Burun Boğaz Hastalıkları Kliniği, Kumluca Devlet Hastanesi, Antalya.

e-posta: drmuratkar@gmail.com

Geliş tarihi / Received: Ocak / January 10, 2013; Kabul tarihi / Accepted: Şubat / February 22, 2013 ;

Online yayın tarihi / Published online: Mayıs / May 4, 2013
}

Çevrimiçi erişim / Online available at: www.jmedupdates.org doi:10.2399/jmu.2013001009 Karekod / QR code: 
Helikobakter pilori ( $H$. pylori) enfeksiyonu dünyada en sik görülen kronik bakteriyel enfeksiyondur. ${ }^{[1]}$ Dünya nüfusunun \%60'inın bu bakteri ile kolonize oldugu tahmin edilmektedir. Sıklığı ve sebep olduğu hastalıklar açısından $H$. pylori ciddi bir halk sağllğ̣ sorunudur. ${ }^{[1,2]} H$. pylori çubuk şeklinde, spiral, gram negatif, mikroaerofilik bir mikroorganizmadır. ${ }^{[3]}$ Kronik aktif gastrit, peptik ülser hastalığı, mide kanseri ve mide mucosa-associated lymphoid tissue (MALT) lenfomanın etiyolojisinden sorumlu olduğu bilinmektedir. $H$. pylori ayrıca aterosklerozis, diabetes mellitus ve insülin direnci gibi gastrointestinal sistem dışı bazı hastalıkların etiyopatogenezinde de suçlanmaktadır. ${ }^{[1,2]}$

Batı ülkelerinde enfeksiyonun prevalansı \%25-50 arasinda değişmekte olup giderek düşmektedir. Gelişmekte olan ülkelerde toplumun büyük kısmı $H$. pylori ile enfektedir. $^{[4]} H$. pylori ile enfekte kişiler kronik bir enflamasyona maruz kalmaktadır. ${ }^{[5]}$

Serbest radikaller, atomlardaki elektronlar orbital denilen bölgelerin içinde yer alır. Her orbital birbirine zıt yönde yerleşimli en fazla iki elektron içerebilir. Serbest radikaller ise en dış orbitalinde bir veya daha fazla eşleşmemiş elektron taşıyan kısa ömürlü bileşiklerdir. Bu nedenle kararsız bir yapı özelliği gösteren serbest radikaller diğer organik ve inorganik moleküllerle reaksiyona girebilme yeteneğine sahiptirler. ${ }^{[6]}$ Aerobik organizmalarda serbest radikallerin başlıca kaynağı moleküler oksijendir. Oksijen moleküllerinin \%95-99'u oksidatif fosforilasyon sirasinda mitokondriyal stokrom oksidazları ile 4 e- alarak suya dönüştürülmekte ve sonuçta ATP elde edilmektedir. Fakat bu süreçte oksijenin \% 1-3 kadarı tam olarak suya dönüşemez ve hidroksil radikali ile süperoksit anyon radikali meydana gelir. İnsan vücudunda oluşan radikallerin büyük bir kısmı oksijenden türemektedir. Zira oksijen elektronlar1nın ikisi eşleşmemiş şekilde dağılmıştır. Bu yüzden oksijen "diradikal" olarak değerlendirilmektedir. Oksijen bu özelliğinden dolayı diğer serbest radikallerle kolayca reaksiyona girebilir. ${ }^{[7]}$

H. pylori, çocukluk çă̆ında kazanılan bir enfeksiyondur. Fakir ülkelerde çocuklar, bu bakteriyi 2-8 yaşında almaktadır. ${ }^{[8]}$ On yaş civarındaki çocukların \% 75'i enfeksiyonu kazanmış durumdadır. Çocukluk çağında, enfeksiyon eradike edilse bile reenfeksiyon sorun olmaktadır. Fakir ülkelerde, yetişkinlerin \% 80'den fazlası $H$. pylori ile enfektedir. ${ }^{[9]}$ Enflamasyonda oksidatif stres artmaktadır. ${ }^{[10]}$ Artan oksidanlar ve azalan antioksidanlar ateroskleroz ve kanser için bir zemin hazırlamaktadır. ${ }^{[1]]}$

Bu çalışmada, larengofarengeal reflülü hastalarda, $H$. pylori serum IgG pozitifliği, total antioksidan kapasite, to- tal oksidan seviye ve oksidatif stres indeksi arasındaki ilişki araştırılmıştır.

\section{Gereç ve Yöntem}

Bu prospektif çalışma, Temmuz 2007 ile Aralık 2008 tarihleri arasinda, Harran Üniversitesi Tip Fakültesi KBB Anabilim Dalı'nda yürütülmüştür.

\section{Hastalar}

Harran Üniversitesi Tıp Fakültesi KBB Anabilim Dalı'na larengofarengeal reflü (LFR) şikayeti ile başvuran 48 hasta çalışma grubuna alınmıştır. Bu hastalardan, H. pylori $\operatorname{IgG}(-)$, LFR (+) olan 20 hasta Grup 2 ve H. pylori $\operatorname{IgG}(+)$, LFR (+) olan 28 hasta Grup 3 olarak çalışmaya alınmıştır. Kontrol grubunu (Grup 1) ise, KBB rahatsızlığı olmayan sağlıklı 19 birey oluşturmuştur. Nörolojik hastalı̆̆ 1 (mental retardasyon, serebral palsi vb), kraniyofasiyal anomalisi (yarik damak vb), sindirim sistemi anomalisi bulunanlar ile takip ve tedaviye uyum sağlamayan olgular çalışma dışı b1rakıldi.

\section{pH Metre Monitörizasyon}

Çalışmaya dahil edilen olgulara 24 saatlik çift kanallı $\mathrm{pH}$ metre monitörizasyonu yapıld1. H2 reseptör antagonistleri işlemden 4 gün önce kesildi, saatlik $\mathrm{pH}$ metre monitörizasyonu sırasında gazlı, asitli, baharatlı ve sıcak yiyecek ve içeceklerin alınmasına sadece yemek esnasında veya sonunda izin verildi. İşlem 4-6 saatlik bir açlık süresinden sonra yapıldı. MMS-Medical Measurement Systems Orion Ambulatuar pH Metre Sistemi" ile "Synectics Portugal pH Kateteri Çift Sensor 15 cm” pH kateteri kullanılarak $\mathrm{pH}$ metre monitörizasyonu uyguland. İşlem öncesinde her iki prob pH $7.00 \pm 0.005$ ve $\mathrm{pH} 0.95 \pm 0.005$ buffer solüsyonlarında kalibre edildi. Çalışma ve kontrol gruplarına çift kanallı ayaktan 24 saatlik pH monitörizasyonu uygulandi. Lidokain içeren topikal spreyle nazal lokal anestezi sağlandıktan sonra, kateter transnazal fleksibil nazofarenözofagoskop eşliğinde, proksimal kanal işaret bandı aritenoidlerin hemen arkasina ve üst özofagus sfinkterinin $1 \mathrm{~cm}$ proksimaline gelecek şekilde yerleştirildi. Distal sensör ise proksimal sensörden $15 \mathrm{~cm}$ ilerde ve alt özofagus sfinkterinin $5 \mathrm{~cm}$ proksimalinde olacak şekilde yerleştirildi. Prob yerleştirme, programın yönlendirdiği şekilde yapılmış olup, proksimal ve distal kanal $\mathrm{pH}$ değerleri de anlık olarak PC'den ekranda görülebildi.

İnceleme sonunda monitörizasyon cihazındaki veriler, veri aktarma alt birimi ile kişisel bigisayara nakledildi. $\mathrm{pH}$ değerlerinde 4.0'ün altında olan düşüşler reflü olarak kabul 
edildi (Şekil 1). pH monitörizasyonu ile her iki kanaldan "toplam", "ayakta" ve "yatarken", "pH'nın 4.0'ün altında olduğu süre yüzdesi”, "reflü episod sayısı", "en uzun reflü süresi" ve distal kanal için "DeMeester skoru" parametreleri elde edildi. ${ }^{[12]}$

Yirmi dört saatlik kayıt işlemi sonrasında bilgiler "MMS Database DbMMS v7.3, The Netherlands" programı kullanılarak değerlendirildi. Tüm bulgular bir arada değerlendirilerek elde edilen $\mathrm{pH}$ monitörizasyonu değerleri, toplam inceleme süresi içerisindeki $\mathrm{pH} 4.0$ 'ün altındaki yapılan ölçümlerin yüzdesi ve reflü sıklığı araştırıldı. Distal probtaki $\mathrm{pH}$ seviyesinin 4.0'ün altındaki zamanı ve bunun yüzdesi 3 ayrı pozisyonda ayrı ayrı hesaplanarak ayakta, yatarken ve toplam olarak değerlendirildi. Proksimal kanalda bir ve daha fazla sayıda, distal kanaldaki pH'ın 4.0'ün altına düşmesini takip eden $\mathrm{pH}$ 4.0'ün altına düşmesi reflü atağı olarak kabul edildi. Bu olgularda larengofarengeal reflü pozitif olarak kabul edildi.

\section{Total Antioksidan Kapasite}

Erel tarafindan geliştirilen tam otomatik bir yöntem olup, güçlü serbest radikallere karşı vucudun total antioksidan kapasitesini ölçen bir metoddur. Reaktifler: Reaktif 1; $75 \mathrm{mM}$ Clark tamponu ( $\mathrm{pH}=1.8)$ içerisinde $10 \mathrm{mM}$ o-Dianisidine ve $45 \mathrm{AM} \mathrm{Fe}\left(\mathrm{NH}_{4}\right) 2\left(\mathrm{SO}_{4}\right) 2-6 \mathrm{H}_{2} \mathrm{O}$ çözülerek hazırlanır. Reaktif 2; $7.5 \mathrm{mM}$ hirojen peroksit $75 \mathrm{mM}$ Clark tamponu $(\mathrm{pH}=1.8)$ içerisinde karıştırılarak hazırlanır. $\mathrm{Fe}^{2+}-\mathrm{O}$-dianisidine kompleksi hidrojen peroksid ile Fenton tipi reaksiyon oluşturarak $\mathrm{OH}$ radikalini oluşturur. Bu güçlï reaktif oksijen türü indirgenerek düşük $\mathrm{pH}$ 'da renksiz o-dianisidine molekülü ile reaksiyona girerek sar1-kahverengi dianisidil radikallerini oluştururlar. Dianisidil radikalleri ileri oksidasyon reaksiyonlarına katılarak renk oluşumu artmaktadır. Ancak örneklerdeki antioksidanlar bu oksidasyon reaksiyonlarını bastırarak renk oluşumunu durdurmaktadırlar. Bu reaksiyon otomatik analizörde spektrofotometrik olarak ölçülerek sonuç verilmektedir. ${ }^{[13]}$

\section{Total Oksidan Seviye}

Erel tarafindan geliştirilen tam otomatik kolorimetrik bir yöntemdir. Reaktiflerin tarifi şöyledir: Reaktif 1; 140 mM'lık NaCI çözeltisi içerisine $25 \mathrm{mM} \mathrm{H}_{2} \mathrm{SO}_{4}$ çözülerek ana solüsyon hazırlanır. Ana solüsyon da önce \%10 oranında gliserol çözülüp daha sonra total volümde $250 \mu \mathrm{M}$ xlenol orange çözülerek hazırlanır. Reaktif 2; ana solüsyon içerisinde önce $10 \mathrm{mM}$ o-dianisidin dihidroklorid çözülüp sonra $5 \mathrm{mM}$ amonyom ferröz sülfat çözülerek reaktif hazırlanır. Prensip: Örnekte bulunan oksidanlar ferröz iyono-dianisidin kompleksini ferrik iyona oksitlerler. Ortamda bulunan gliserol bu reaksiyonu hızlandırarak yaklaşık üç

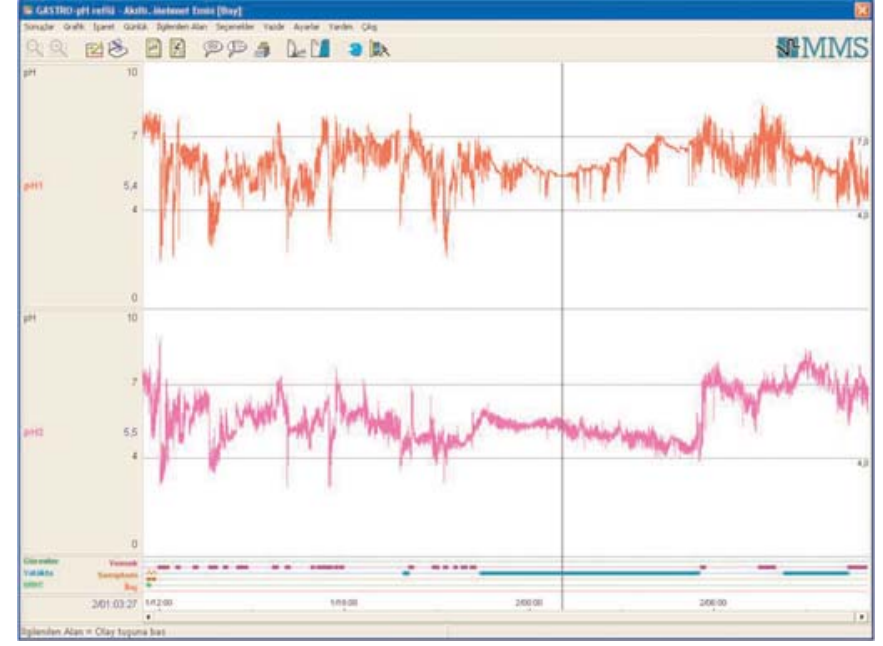

Şekil 1. Yirmi dört saatlik iki kanallı özofageal pH metre monitörizasyon trasesinde, distal kanaldaki pH düşüşü ile paralellik gösteren pH'in 4.0'ün altına düştüğü larengofarengeal reflü atakları.

katına çıkarmaktadır. Ferrik iyonlar asidik ortamda xylenol orange ile renkli bir kompleks oluştururlar. Örnekte bulunan oksidanların miktarıyla ilişkili olan rengin şiddeti spektrofotometrik olarak ölçülmektedir. ${ }^{[14]}$

\section{Oksidatif Stres İndeksi}

Total oksidatif stres (TOS) / total anatioksidan kapasite (TAK) şeklinde bölünerek oksidatif stres indeksi (OSI) hesapland1. ${ }^{[15]}$

\section{İstatistiksel Analiz}

SPSS 1.0 kullanılarak gerekli istatistiksel analizler yapild. Kruskal-Wallis varyans analizi ve Mann-Whitney $U$ testi Bonferroni düzeltmesi ile birlikte uygulandı. p değerinin $<0.05$ olması anlamlı olarak kabul edildi.

\section{Bulgular}

Total antioksidan kapasite (TAK), total oksidan seviye (TOS) ve oksidatif stres indeksi (OSI) sonuçları, Tablo 1'de gösterilmiştir. Her bir TAK, TOS ve OSI değeri için, Grup 1-3 arasındaki fark Kruskal-Wallis varyans analizi ile değerlendirilmiş ve TOS $(\mathrm{p}=0.000)$ ve OSI $(\mathrm{p}=0.000)$ için istatistiksel açıdan anlamlı fark bulunmuştur. Farkı yaratan değeri bulmak için ikili karşılaştırmalar, Mann-Whitney U testi (Bonferroni düzeltmesi ile) yapılmıştır:

Grup 3'ün total oksidan seviye değerleri, Grup 1 ( $\mathrm{p}=0.000$ ) ve Grup 2'den ( $\mathrm{p}=0.000$ ); ve Grup 2'nin total oksidan seviye değerleri, Grup 1'den istatistiksel olarak anlamlı şekilde daha yüksektir. 
Tablo 1. Total antioksidan kapasite, total oksidant seviye ve oksidatif stres indeksi sonuçları.

\begin{tabular}{|c|c|c|}
\hline & \multicolumn{2}{|c|}{$\begin{array}{c}\text { Grup } 1 \text { (Kontrol) } \\
\text { H. pylori IgG (-), } \\
\text { LFR (-) }\end{array}$} \\
\hline & Ortalama & Std. dev. \\
\hline Yaş & 32.05 & 7.96 \\
\hline Total antioksidan kapasite (TAK) & 0.89 & 0.24 \\
\hline Total oksidan seviye (TOS) & 7.38 & 1.43 \\
\hline Oksidatif stres indeksi (OSI) & 0.90 & 0.32 \\
\hline Total oksidan seviye (TOS) & $\mathbf{z}$ & $p^{t}$ \\
\hline Grup 1-2 & -5.255 & 0.000 \\
\hline Grup 1-3 & -5.766 & 0.000 \\
\hline Grup 2-3 & -4.350 & 0.000 \\
\hline \multicolumn{3}{|l|}{ Oksidatif stres indeksi (OSI) } \\
\hline Grup 1-2 & $-4,609$ & 0.000 \\
\hline Grup 1-3 & -5.398 & 0.000 \\
\hline Grup 2-3 & -3.263 & 0.001 \\
\hline
\end{tabular}

*Kruskal-Wallis varyans analizi sonuçları

†Mann-Whitney U testi (Bonferroni düzeltmesi ile birlikte) sonuçları

Grup 3'ün oksidatif stres indeksi değerleri, Grup 1 ( $\mathrm{p}=0.000$ ) ve Grup 2'den ( $\mathrm{p}=0.000$ ) ve Grup 2'nin oksidatif stres indeksi değerleri, Grup 1'den istatistiksel olarak anlamlı şekilde daha yüksektir.

\section{Tartışma}

Serbest oksijen radikallerinin zararlı etkilerini ortadan kaldırmak için insan serum, eritrosit ve dokularında genel olarak antioksidanlar diye adlandırılan bir defans mekanizması mevcuttur. Tüm vücuttaki antioksidan durumu değerlendirmek için total antioksidan kapasite ölçümleri yapılmaktadır. Antioksidanlar, doğal (endojen kaynaklı) ve eksojen kaynaklı antioksidanlar olmak üzere başlıca iki ana gruba ayrılabildiği gibi serbest radikalin meydana gelişini önleyenler ve mevcut olanları etkisiz hale getirenler şeklinde de ikiye ayrılabilirler. Ayrıca enzim ve enzim olmayanlar şeklinde de sinıflandırılırlar. Hücrelerin hem sivı hem de membran kısminda bulunabilirler ve oksidanlara karsı birlikte hareket ederler. Antioksidanlar, hem direkt, hem de dolayl olarak ksenobiyotiklerin, ilaçların, karsinojenlerin ve toksik radikal reaksiyonların istenmeyen etkilerine karşı hücreleri korurlar. En önemli antioksidan enzimler; süperoksit anyonunu $\mathrm{H}_{2} \mathrm{O}_{2}$ 'ye dönüştüren süperoksit dismutaz (SOD), organik peroksitleri detoksifiye eden glutatyon peroksidaz (GSHPx) ve $\mathrm{H}_{2} \mathrm{O}_{2}$ 'yi suya indirgeyen katalazdır. Süperoksit

radikalinin ortadan kaldırılmasında bu enzim sisteminin en önemlisi SOD'dur. Tümör oluşum mekanizması üzerine yapılan son çalışmalarda tümör hücrelerinin süperoksit radikalleri üretebildiği gösterilmiştir. ${ }^{[16-18]}$

Antioksidanların ilk belirlenen etkileri, zar yapısında bulunan lipidlerin peroksidasyona karşı korunması olmuştur. Bunun sonucu olarak, başlangıçta antioksidanlar lipid peroksidasyonunu engelleyen moleküller olarak tanımlanmışlardır. Günümüzde ise, antioksidanların tanımı lipidlerin yanı sıra proteinler, nükleik asidler ve karbonhidratlar gibi diğer hedef molekülleri koruyucu etkilerini de içerecek şekilde genişletilmiştir. Böylece antioksidanlar, hedef molekülleri oksidan hasarı engelleyen ve geciktiren maddeler olarak tanımlamakta ve bu tanımla bağlantılı olarak antioksidanların etkileri farklı şekillerde olabilmektedir. Memeli hücresinde oksidan ürünlere karşı korunma üç prensip içinde gerçekleşmektedir: ${ }^{[19]}$ (1) Oluşan radikallerin detoksifikasyonu, (2) Radikal reaksiyonlarının sona erdirilmesi, (3) Radikal oluşumunun sinırlandırılması.

Bizim çalışmamızda, larengofarengeal reflülü hastalarda, H. pylori Serum IgG pozitifliği, total antioksidan kapasite (TAK), total oksidan seviye (TOS) ve oksidatif stres indeksi (OSI) arasındaki ilişki araştırılmıştır. Her bir TAK, TOS ve OSI değeri için, Grup 1-3 arasındaki fark KruskalWallis varyans analizi ile değerlendirilmiş ve TOS $(\mathrm{p}=0.000)$ ve OSI $(\mathrm{p}=0.000)$ için istatistiksel açıdan anlamlı fark bulunmuştur. Farkı yaratan değeri bulmak için ikili karşılaştırmalar, Mann-Whitney U testi (Bonferroni düzeltmesi ile) yapılmıştır: Grup 3'ün [LFR (+), H. pylori IgG $(+)$ ] total oksidan seviye değerleri, Grup 1 (Kontrol) $(\mathrm{p}=0.000)$ ve Grup 2'den [(LFR (+), H. pylori $\operatorname{IgG}(-)]$ $(\mathrm{p}=0.000)$ ve Grup 2'nin [(LFR (+), H. pylori $\operatorname{IgG}(-)]$ total oksidan seviye değerleri, Grup 1'den istatistiksel olarak anlamlı şekilde daha yüksektir. Grup 3'ün [LFR (+), H. pylori Ig $G(+)$ ] oksidatif stres indeksi değerleri, Grup 1 ( $\mathrm{p}=0.000)$ 
ve Grup 2'den [(LFR (+), H. pylori $\operatorname{IgG}(-)](\mathrm{p}=0.000)$ ve Grup 2'nin [(LFR (+), H. pylori IgG (-)] oksidatif stres indeksi değerleri, Grup 1'den (Kontrol) istatistiksel olarak anlamlı şekilde daha yüksektir.

H. pylori'nin invaziv bir bakteri olmaması, mukus tabakası içinde barınması ve mide bezlerinin lümeni içine saklanabilmesi, konakçının savunma sisteminden korunmasına imkan sağlamaktadır. Konak bağışıklık sistemi, H. pylo-


lığından haberdardır. H. pylori'den açığa çıkan kemotaktik proteinler ile etkilenmiş mide epitelinden açığa çıkan interlökin-8 (IL-8), kemoatraktif protein ve sitokinler, nötrofil ve lenfositlerin ortama göçüne yol açar. Ayrıca mononükleer hücreler ve nötrofillerden salgılanan interlökinler, tümör nekroz faktörü (TNF), interferon, mukozal enflamatuvar cevabın yanı sıra immünolojik yanıtın da oluşmasına yol açar. ${ }^{[2]} H$. pylori'nin ürettiği üreaz, alkol dehidrogenaz $(\mathrm{ADH})$, fosfolipaz ve proteolitik enzimler, mukus ve mide epiteli için toksik etkilidir. ADH'ın meydana getirdiği asetaldehit, mukozal hücrelere toksiktir. Fosfolipaz, izolesitin meydana gelmesine neden olur, bu da mide epitelinde hasara yol açar. ${ }^{[21,22]} H$. pylori'nin kendini savunmak amaciyla geliştirdiği uyum mekanizmalarından en önemlisi, süperoksit dismutaz (SOD) ve katalaz üretmesidir. Bu iki enzim, nötrofillerin fagositik vakuolünde $H$. pylori'nin yok edilmesini önlemektedir. SOD, süperoksiti hidrojen peroksite dönüştürür; katalaz da hidrojen peroksiti, oksijen ve suya parçalar. SOD aktivitesinden yoksun mutant $H$. pylori hayatta kalamaz. H. pylori oksidaz aktivitesine de sahiptir. ${ }^{[23]}$

H. pylori enfeksiyonunun gastrik mukozada oksidatif strese yol açarak, mukozal hasar yaptığı bildirilmiştir. Nüklear faktör eritroid-2 bağlantılı faktör 2 (Nrf2) hücrelerde antioksidan cevabı düzenlemektedir. ${ }^{[2]}$

Çekin ve ark. ${ }^{[25]}$ larengeal kitle ile başvuran 43 hastada, önceden tedavi edilmemiş $H$. pylori ve LPR varlığını araştırmışlardır. H. pylori 24 hastada (\%55.8) mevcuttur, 19 (\%44) hastada bulunmamıştır ve anlamlı fark saptanmamıştır. Larengofarengeal reflü prevalansı $H$. pylori prevalansından daha yüksektir; 30 hastada (\%69.8) saptanmıș ve 13 (\%30.2) hastada saptanmamıștır. Fark $(\mathrm{p}=0.01)$ istatistiksel olarak anlamlı bulunmuștur. $H$. pylori ve LFR durumu arasında hiçbir ilişki bulunmamış ve LFR pozitifliği ile malign/premalign larengeal lezyonların $(\mathrm{p}=0.03)$ varlığı arasında anlamlı bir ilişki bulunmuştur.

Bizim sonuçlarımız, tek başına LFR varlığı veya $L F R$ ve $H$. pylori' ye karşı gelişen serum IgG antikor seviyesindeki artışın, total oksidan seviye ve oksidatif stres indeksinde artmaya yol açtı̆̆ını göstermektedir. Buna karşılık, total antioksidan kapasite üzerine anlamlı bir etki olmamaktadır. Bu sonuçlara bakılarak, hem LFR varlığ pylori ile enfekte olunması ve $H$. pylori'ye karşı IgG antikorlarının gelişmesi, vücutta total oksidan seviye ve oksidatif stres indeksinde artışa yol açarak, sonuçta serbest radikallerde ve vücutta oksidatif streste artışa yol açmaktadır. Bilindiği gibi oksidatif stres dokuda hasara yol açan bir durumdur. Bu nedenle, özellikle tek başına LFR varlığı veya LFR ve $H$. pylori'ye karşı gelişen serum IgG antikor seviyesindeki artış bulunan hastalarda bu oksidatif stresi azaltmak için ontioksidan özelliği olan E vitamini, C vitamini gibi ilaçların da tedaviye eklenmesi, doku seviyesinde oksidatif stresi azaltacak ve serbest radikallere bağlı olarak gelişen hasar azalacaktır.

Çıkar Çakışması / Conflict of Interest: Çıkar çakışması bulunmadığı belirtilmiştir.

\section{Kaynaklar}

1. Cave DR. Transmission and epidemiology of Helicobacter pylori. Am J Med 1996;100:12-7.

2. Wyle FA. Helicobacter pylori: current perspectives. J Clin Gastroenterol 1991;13:114-24.

3. Goodwin CS, Worsley BW. Microbiology of Helicobacter pylori. Gastroenterol Clin North Am 1993;22:5-19.

4. Dunn Be, Cohen H, Blaser MJ. Helicobacter pylori. Clin Microbiol Rev 1997;10:720-41.

5. Megraud F. Epidemiology of Helicobacter pylori infection. Gastroenterol Clin North Am 1993;22:73-88.

6. Perinondi Nl, Thomson W, Schmid Hho. Diabetic heart and kidney exhibit creased resistance to lipid peroxidation. Biochim Biophys Acta 1990;1047:63-9.

7. Freeman BA, Crapo JD. Biology of disease free radicals and tissue injury. Lab Invest 1982;47:412-426.

8. Graham DY. Helicobacter pylori infection in the pathogenesis of duodenal ulcer and gastric cancer: a model. Gastroenterology 1997:113:1983-91.

9. Rowland M, Drumm B. Clinical significance of Helicobacter pylori infection in children. Br Med Bull 1998;54:95-103.

10. Emst P. Review article: the role of infiammation in the patho genesis of gastric cancer. Alim Pharmacol Therapeut 1999;13: $13-8$.

11. Halliwell B, Gutteridge JMC. Free Radicals in Biology and Medicine. 3rd ed. Oxford: Oxford Science Publications; 1999.

12. Mainie I, Tutuian R, Castell DO. Comparison between the combined analysis and the DeMeester Score to predict response to PPI therapy. J Clin Gastroenterol 2006;40:602-5.

13. Erel O. A novel automated method to measure total antioxidant response against potent free radical reactions. Clin Biochem 2004;37:112-9.

14. Erel O. A new automated colorimetric method for measuring total oxidant status. J Clin Biochem 2005;47:119-29. 
15. Harma M, Harma M, Kocyigit A, Erel O. Increased DNA damage in patients with complete hydatidiform mole. Mutat Res 2005;583:49-54.

16. Jaund AF; Role of free radicals in cancer development. Eur J Cancer 1996;32:30-38

17. Yang MH, Schaich KM. Factors affecting DNA damage caused by lipid hydroperoxides and aldehydes. Free Radic Biol Med 1996;20:225-36.

18. Salin ML, Mccoard JM. Free radical and inflammation. Protection of phagocytosine leukocytes by superoxide dismutase. J Clin Invest 1975;56:1319-23.

19. Burton G, Traber M. Antioxidants action of carotenoids. J Nutr 1989;119:109-11.

20. Harris PR, Mobley HLT, Perez-Perez GI, Blaser MJ, Smith PD. Helicobacter pylori urease is a potent stimulus of mononuclear phagocyte activation and inflammatory cytokine production. Gastroenterology 1996;111:419-25.
21. Figura N. Are Helicobacter pylori differences important in the development of Helicobacter pylori-related diseases? Ital J Gastroenterol Hepatol 1997;29:367-74.

22. Langton SR, Cesareo SD. Helicobacter pylori associated phospholipase A2 activity: a factor in peptic ulceration. J Clin Pathol 1992;45:221-4.

23. Ernst PB, Pecquet S. Interaction between Helicobacter pylori and the local mucosal immune system. Scand J Gastroenterol Suppl 1991;187:56-64.

24. Buommino E, Donnarumma G, Manente L, et al. The Helicobacter pylori protein $\mathrm{HspB}$ interferes with $\mathrm{Nrf2/Keap1}$ pathway altering the antioxidant response of Ags cells. Helicobacter 2012;17:41725 .

25. Cekin E, Ozyurt M, Erkul E, et al. The association between Helicobacter pylori and laryngopharyngeal reflux in laryngeal pathologies. Ear Nose Throat J 2012;91:E6-9.

Bu açık erişim makalenin, ticari kullanım amacı ve içerik değişikliği dışında kalan çoğaltma, dağıtma vb. tüm kullanım hakları, bilinen standartlarda kaynak olarak gösterilmesi koşuluyla Creative Commons Attribution-NonCommercial-NoDerivs 3.0 Unported (CC BY-NC-ND3.0) Lisansı aracılı̆̆ılyla (http://creativecommons.org/licenses/by-nc-nd/3.0/) bedelsiz kullanıma sunulmuştur.

Makalenin atıf kïnyesi: Mutlu Ö, Kar M, Yıldız Zeyrek F, Aksoy N, Taşkın A. Helicobacter pylori serum IGG’si pozitif olan larengofarengeal reflülü olgularda total antioksidan kapasite, total oksidan seviye ve oksidatif stres indeksi. J Med Updates 2013;3(1):25-30. 